Check for updates

The BMJ

Cite this as: $B M J 2020 ; 370: m 3066$ http://dx.doi.org/10.1136/bmj.m3066 Published: 31 July 2020

\section{Covid-19: Tighter restrictions imposed in the north of England as cases spike}

\section{Elisabeth Mahase}

People in Greater Manchester, Lancashire, and West Yorkshire are no longer allowed to have visitors in their homes or gardens-they can still visit shops, restaurants, and pubs but cannot mix households while they are there, new government guidance has said.

The new local restrictions have been imposed because of a rising number of covid-19 cases, said Andy Burnham, the mayor of Greater Manchester. They will be reviewed weekly. "Over recent days, there has been a marked change in the picture across Greater Manchester with regard to the spread of covid-19. We have gone from a falling rate of cases in nearly all of our boroughs last week to a rising rate in nine out of 10, affecting communities across a much wider geography," he said in an official statement.

The areas affected include: Greater Manchester (City of Manchester, Trafford, Stockport, Oldham, Bury, Wigan, Bolton, Tameside, Rochdale, Salford), Lancashire (Blackburn with Darwen, Burnley, Hyndburn, Pendle, Rossendale), and West Yorkshire (Bradford, Calderdale, Kirklees).

Case numbers vary substantially between the affected areas for the week ending 26 July, from 91 cases per 100 ooo people in Blackburn and Darwen (a rise of 10 from the week before) and 57 cases $(+38)$ in Oldham, to 8 cases per 100000 in Wigan $(+4)$, and 6 cases $(-3)$ in Rossendale.

Julian Tang, honorary associate professor in respiratory sciences at the University of Leicester, said that the new restrictions "make sense from a virus control angle" as it is "natural to get physically closer with people you know, such as at garden parties and indoors with families and friends that we have not seen for several months."

But the government has been criticised for its poor communication, with just a few hours' notice given, and has been accused of shifting the blame onto black and minority ethnic communities.

Health secretary Matt Hancock caused confusion when explaining the new rules, as he seemed to contradict the government guidance on households travelling to meet outside of the affected areas. Speaking to the BBC, Burnham was asked about the confusion. He said, "They [the government] made this statement to the media last night, but it then took some hours for the guidance, as we have got it, to appear.”

Keir Starmer, leader of the opposition party (Labour), also criticised the way the announcement was made. He posted on social media, "No one would argue with putting in place local action to reduce the transmission of coronavirus. But announcing measures affecting potentially millions of people late at night on Twitter is a new low for the government's communications during this crisis. When the government ended the daily press conferences, they said they would hold them for 'significant announcements,' including local lockdowns. It's hard to imagine what could be more significant than this."1

When announcing the restrictions, Hancock seemed to blame people in the affected areas for not following the rules. Meanwhile, a fellow conservative MP Craig Whittaker (Calder Valley) has blamed the black, minority ethnic, and Muslim communities for the outbreak. ${ }^{2}$ The restrictions on household mixing came as Muslim communities prepared to celebrate Eid al-Adha, which usually involves families meeting.

Manchester GP Siema Iqbal told The BMJ that the government's announcement was "ill-timed and lacked clarity." She said, "If anything, it created more confusion. The rhetoric seems to suggest that blame incorrectly lies at the south Asian communities. This completely ignores the fact that actually many have adhered to the rules, but due to social deprivation and overcrowded housing it means risk of transmission is higher, especially if two families mix as part of a social bubble.

“The timing also ignores the fact that the rise isn't just in boroughs of high ethnic diversity but also other areas, and this is due to younger people mixing at, for example, house parties. The government should have planned this better and been clearer with their messaging rather than acting like they were sending a 5pm email on a Friday. But it's just another example of how poorly the whole pandemic had been managed."

Meanwhile, Hina Shahid, chair of the Muslim Doctors Association and GP, told The BMJ that there is "an overwhelming feeling in BAME communities that we are being scapegoated for systematic government failings in handling the crisis."

She said, "There are reports of increasing racist and Islamophobic attacks on communities. At a time when solidarity and compassion are needed to support vulnerable communities, divisive government and media narratives are creating heightened fear, mistrust, and stigma.” 
Shahid said that her association had also written multiple policy briefings and letters to the government to "highlight the structural inequalities, discrimination, and racism that are the main drivers for covid-19 transmission," but had received no response.

"The Muslim community is angry at not being consulted or forewarned. This is a community that is already among the most marginalised and excluded in the UK. Muslims had made travel plans, booked tickets, and prepared meals, only to be given just over two hours' notice on the equivalent to Christmas Eve regarding restrictions. It has already been a difficult time for us, with Muslims over-represented among covid-19 deaths and frontline NHS worker deaths. The last Eid was celebrated under lockdown. We were looking forward to celebrating Eid safely, with the vast majority complying with Public Health guidance. We feel let down and this further undermines trust in the government."

1 https://twitter.com/Keir_Starmer/status/1288961128488415235

2 https://www.lbc.co.uk/radio/presenters/ian-payne/muslim-bame-communities-coronavirus-pandemic/

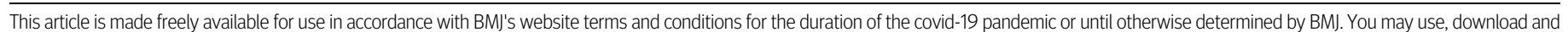
print the article for any lawful, non-commercial purpose (including text and data mining) provided that all copyright notices and trade marks are retained. 